\author{
A.Sh. Zhanzhaxina ${ }^{1}$, Ye.M. Suleimen ${ }^{2,3^{*}}$, M.Yu. Ishmuratova ${ }^{4}$, \\ Zh.B. Iskakova ${ }^{1}$, T.M. Seilkhanov ${ }^{2}$, D.A. Birimzhanova ${ }^{1}$, R.N. Suleimen ${ }^{1}$ \\ ${ }^{1}$ L.N. Gumilyov Eurasian National University, Nur-Sultan, Kazakhstan; \\ ${ }^{2}$ Sh. Ualikhanov Kokshetau State University, Kazakhstan; \\ ${ }^{3}$ Republican collection of microorganisms, Nur-Sultan, Kazakhstan; \\ ${ }^{4}$ Karagandy University of the name of academician E.A. Buketov, Kazakhstan \\ (Corresponding author's e-mail: syerlan75@yandex.kz)
}

\title{
Essential oil of Pulicaria vulgaris (prostrata) and its biological activity
}

\begin{abstract}
The investigation of the chemical composition, antioxidant and cytotoxic activities of the essential oil of Pulicaria vulgaris wild growing in Akmola region, Kazakhstan was the aim of the study. The essential oil was obtained by hydrodistillation and analyzed by gas chromatography-mass spectrometry (GC/MS). A total of 49 compounds were identified representing $86.4 \%$ and the major components were patchoulane (37.4\%), buddledin C (13.9\%), T-cadinol (4.7\%), trans-sesquisabinene hydrate (4.1\%), dyhydro- $\beta$-agarofuran $(2.7 \%),(\mathrm{Z})-\alpha$-atlantone $(1.8 \%)$ and corymbolone $(1.2 \%)$. Six components were identified as unknown $(2.6 \%)$. The antioxidant activity was evaluated by using 2,2-diphenyl-1-picrylhydrazyl (DPPH) free radical scavenging and the essential oil demonstrated an average scavenging effect at 0.75 and $1 \mathrm{mg} / \mathrm{ml}$ concentrations compared with butylhydroxyanisole (BHA). The antiradical activity results of the $P$. vulgaris essential oil is published for the first time. Cytotoxic activity assay was studied against Artemia salina larvae and it can be concluded that the essential oil has a good lethal toxicity in all tested concentrations $(10-1 \mathrm{mg} / \mathrm{ml})$. The authors attribute this result to the presence of the patchoulane as a major component, which is known for its activity against ovarian cancer cells.
\end{abstract}

Keywords: Pulicaria vulgaris (prostrata), essential oil, water distillation, GC/MS, patchoulane, antioxidant, cytotoxic activities.

\section{Introduction}

Pulicaria Gaertn. is a plant genus in the family of Asteraceae (Compositae) with approximately 80 species which are widely distributed in Europe, North Africa and Asia [1]. A review of the literature showed that the genus Pulicaria has been associated with various biological activities, such as $P$. inuloides known as «sekba», is used in Yemen to treat wounds, P. jaubertii is distributed in the southern Arabian Peninsula, and is used traditionally as a diuretic and antipyretic, $P$. stephanocarpa, known as «derbeb» in Soqotra, has been traditionally used in a variety of health conditions including headache, abscesses, boils and sores, P. undulata, known as «kho'ah», is used in the central Sahara to treat chills, diabetes, cardiac disorders, skin diseases, and abscesses, and in Egypt to treat inflammation, as an insect repellent, and an herbal tea [2]. The essential oil of $P$. inuloides has showed antimicrobial and antioxidant (DPPH) activities and the main components were carvotanacetone (47.3\%) and palmitic acid (12.8\%) [3], the major component of P. jaubertii was carvotanacetone $(64.0 \%)$ and the oil was active against MCF-7 and Hep-G2 cells $\left(\mathrm{IC}_{50}=3.8\right.$ and $5.1 \mu \mathrm{g}$ $\mathrm{ml}^{-1}$, respectively) [4], P. stephanocarpa contained $\alpha$-cadinol (42.5\%), $\beta$-caryophyllen (10.8\%), spathulenol $(6.8 \%)$ and it had high antimicrobial and antioxidant ( $\left.\mathrm{DPPH}, \mathrm{IC}_{50}=330 \mu \mathrm{g} \mathrm{ml}^{-1}\right)$ [5] properties, P. odora $\mathrm{L}$. contained thymol (47.8\%) and thymol isobutyrate (30.0\%) and it was active in antibacterial assay [6].

The essential oil of $P$. undulata was studied by different scientist from different countries and the results were signicantly different from each other. For instance, the oil from Algeria contained mainly carvotanacetone $(14.8 \%), \delta$-cadinene $(8.2 \%), \alpha$-cadinol $(4.7 \%)$ and thujanol $(4.7 \%)$ [7]. The oil from Yemen contained carvotanacetone (91.4\%), 2,5-dimethoxy-p-cymene (2.6\%) and it has demonstrated good antimicrobial and moderate cytotoxic activities against MCF-7 cells $\left(\right.$ IC $\left.50=64.6 \pm 13.7 \mu \mathrm{g} \mathrm{ml}^{-1}\right)$ [8]. The oil from Egypt contained carvacrol $(46.5 \%)$, xanthoxylin $(18.1 \%)$, carvotanacetone $(8.7 \%)$ and it had a powerful antioxidant, a good antiacetylcholinesterase (IC50 $=139.2 \mu \mathrm{g} \mathrm{ml}^{-1}$ ), moderate cytotoxic against three cell lines (A375, T98G, HCT116) activities [9]. The oil from Iran contained 4-terpineole (20.1\%), 1S-ciscalamenene (13.4\%), junipene (8.7\%), cis-sabinene hydrate (8.3\%) and $\gamma$-terpinene (7.0\%) [10].

\footnotetext{
${ }^{*}$ Corresponding author
} 
Pulicaria vulgaris (prostrata) Gaertn (Asteraceae) is an herbaceous annual plant, erect, more than $30 \mathrm{~cm}$ high, much branched. The leaves are linear-oblong, subobtuse orsubacute, mucronate, sessile, cordate semiamplexicaul, entire or denticulate. It grows on the wet banks of rivers and lakes, meadow depressions of bumpy sands. It is found in all areas of Kazakhstan, excepting mountains area. It is used as a remedy for dysentery in folk medicine [11]. Italian scientists studied before the essential oil of $P$. vulgaris and its antimicrobial activity, and the main components were hexadecanoic acid $(21.7 \%), \beta$-caryophyllene $(14.3 \%)$ and geranyl propionate $(8.2 \%)$. The oil showed a quite good antimicrobial activity against gram positive bacterial strains [12]. According to the study of Iranian scientists, the main components of this essential oil were thymol $(50.2 \%)$, carvotanacetone $(20.2 \%)$, thymolisobutyrate $(16.9 \%)$, menthan-2-one $(4.3 \%)$, 1-methyl1,2-propanedione $(4.1 \%), 2,5$-dimethoxy-p-cymene (4.0\%), myrtenol (1.2\%) and it has showed antimicrobial and antifungal activities. Also in this study, the cytotoxic activity of essential oil was tested against MCF-7 and Hep-G2 cell lines ( $\mathrm{IC}_{50}=5.36$ and $7.16 \mu \mathrm{g} \mathrm{ml}^{-1}$ respectively) [13]. The results of other study have shown that essential oil of $P$. vulgaris may serve as an alternative or complementary treatment for leishmaniasis [14].

The purpose of this study is to determine the component composition of essential oil of $P$. vulgaris from Kazakhstan, which has great prospects, to test its cytotoxic and antiradical activity and compare with previous studies.

\section{Experimental}

The plant material of P. vulgaris (Asteraceae) was collected during the flowering period on September 1, 2017, near Eski Koluton village, in Astrakhan District, Akmola region, Kazakhstan. A voucher specimen (No. 1996.07.27.02.04.) was deposited in the Herbarium of the Biology and Geography Faculty, E.A. Buketov Karaganda State University.

The essential oil was distilled from the dried aerial parts using a Clevenger-type water distillation apparatus for two hours. Hexane was used as a trap for essential oil. Determination of chemical composition of the essential oil was carried out on the Clarus-SQ 8 (Perkin Elmer) Gas Chromatograph equipped with Massspectrometer (GC/MS apparatus).

Preparation of sample: $25 \mathrm{mg}$ of the essential oil were placed into a $25 \mathrm{ml}$ volumetric flask, dissolved in $15 \mathrm{ml}$ of hexane, adjusted to volume and stirred until complete mixing of the oil.

Chromatographic conditions: capillary column - RestekRxi ${ }^{\circledR}-1 \mathrm{~ms} 0.25 \mathrm{~mm} \times 30 \mathrm{~m} \times 0.25 \mu \mathrm{m}$, sample volume: $1.0 \mu \mathrm{l}$, carrier gas - He, carrier gas speed: $1 \mathrm{ml} \mathrm{min}^{-1}$, split ratio 1:25, temperature of column: $40^{\circ} \mathrm{C}$, rise of $2{ }^{\circ} \mathrm{C} \mathrm{min}^{-1}$ to $280{ }^{\circ} \mathrm{C}$, temperature of evaporator $-280^{\circ} \mathrm{C}$, mass spectrometric detection: temperature $-240{ }^{\circ} \mathrm{C}, \mathrm{EI}^{+}=70 \mathrm{eV}$, the scanning time from 4 to 120 minutes, the scan mode ion $39-500 \mathrm{~m} / \mathrm{z}$. The percentages of components are automatically calculated based on the total peak areas of the chromatogram of ions (Fig. 1). Components were identified by mass spectra and the retention times, with use of NIST library.

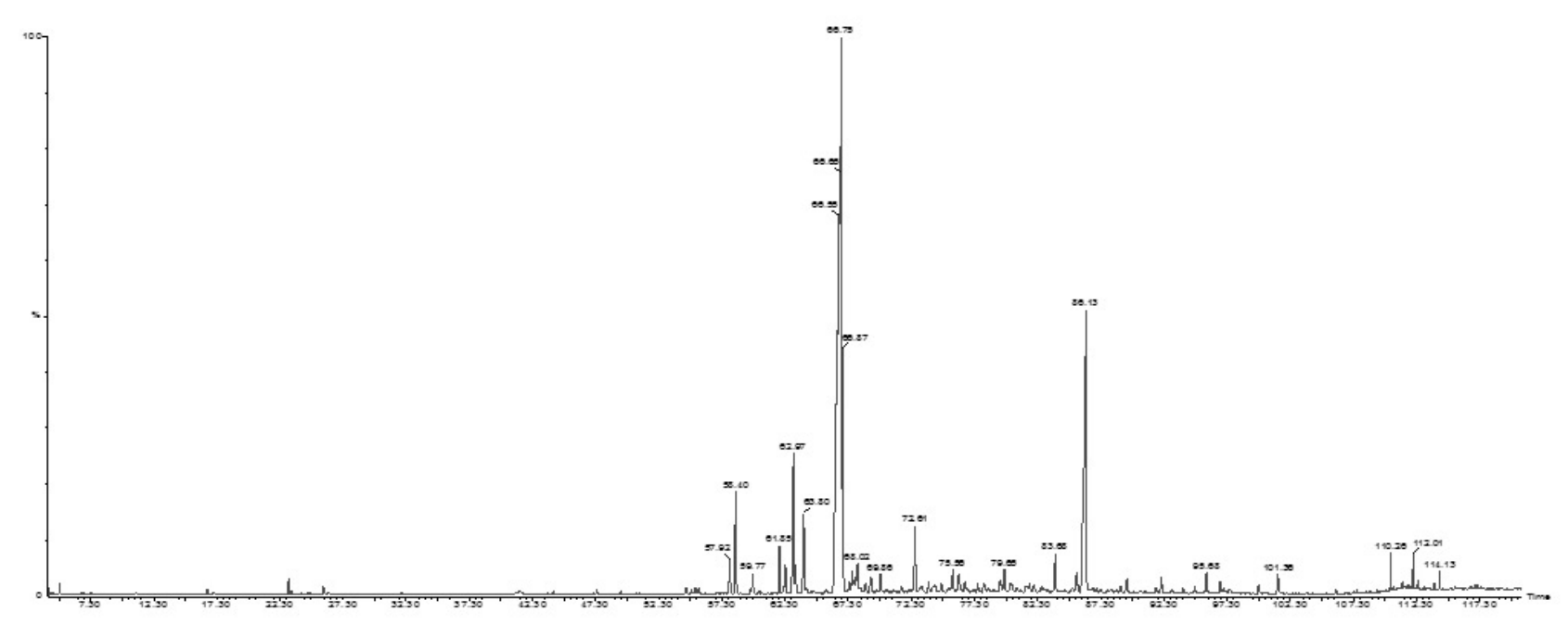

Figure 1. Chromotogram of GC/MS experiment of the essential oil of $P$. vulgaris 


\section{Antiradical activity of the essential oil}

The antiradical activity of the essential oil was performed in regard to 2,2-diphenyl-1-picrylhydrazyl radical (DPPH). The dependence of the analyte absorbance on the concentration were measured on a spectrophotometer Cary $60 \mathrm{UV}-\mathrm{Vis}$ at $520 \mathrm{~nm}$ wavelength. Antiradical activity of the essential oil was compared with butylhydroxyanisole (BHA). The values of antiradical activity (ARA) were calculated using the formula shown below:

$$
\operatorname{ARA}(\%)=\frac{\left(A_{0}-A_{t}\right)}{A_{0}} \times 100 \%,
$$

where $A_{0}$ - is the optical density of control; $A_{t}$ - is the optical density of the working sample.

DPPH molecule forms a free radical that is stable in different medium and wide range temperature, due to the maximum freedom of the electron delocalization over the entire molecule and spatial shielding atoms bearing the greatest spin density as well as the lack of hydrogen atoms in the positions where may occur the isomerization or disproportionation. In addition, delocalization is causing intense violet color of this radical in the aqueous-alcoholic media, the interaction with the antioxidant, capable of donating a proton; there is a restoration of the radical, resulting in the violet color turns into yellow.

\section{Cytotoxic activity of essential oil}

The $55 \mathrm{ml}$ separator funnel was filled with artificial seawater and added $200 \mathrm{mg}$ eggs of Artemia salina. Then, it was kept with a soft supply of air for three days, until the crustaceans hatch from eggs. The one side of funnel was covered with aluminum foil, and after 5 minutes, the nauplii, which moved on the bright side of the separator funnel, were removed with a Paster pipette.

20-40 nauplii were placed into each of the 24 micro titer plates with $990 \mu 1$ of seawater. Dead larvae were counted under a microscope. $10 \mu \mathrm{l}$ of dimethylsulfoxide solution per $10 \mathrm{mg} \mathrm{ml}^{-1}$ sample was added. Actinomycin D or staurosporine was used as a standard comparison reagent, and DMSO was a negative control. After 24 hours of incubation and further maintaining micro titer plates for 24 hours (to ensure immobility) the dead larvae were counted under the microscope.

Mortality $P$ was determined by the following formula:

$$
P=\frac{(A-N-B)}{Z} \times 100 \%,
$$

where $A-$ is the amount of dead nauplii after $24 \mathrm{~h} ; N-$ is the amount of nauplii died before the test; $B-$ is the average amount of nauplii died in a negative control; $Z$ - is the total amount of larvae [13].

Results of the study the cytotoxic activity of the essential oils are shown in the Table 4.

\section{Results and Discussion}

The main components of the studied essential oil are presented in the Table 1 . The analytical results revealed the presence of forty nine compounds representing $86.4 \%$. The essential oil of $P$. vulgaris has as the major compounds: patchoulane (37.4\%), buddledin C (13.9\%), T-cadinol (4.7\%), trans-sesquisabinene hydrate $(4.1 \%)$, dyhydro- $\beta$-agarofuran $(2.7 \%),(Z)$ - $\alpha$-atlantone $(1.8 \%)$, dehydronerodiol $(1.3 \%)$ and corymbolone $(1.2 \%)$. These main compounds put together $(65.8 \%)$ of the total chemical composition.

T a b l e 1

\begin{tabular}{|c|c|c|c|c|c|c|c|}
\hline $\mathrm{L}_{\text {literature }}$ & $\mathrm{R}_{\text {calc }}$ & Compound & $\begin{array}{c}\text { Area, } \\
\%\end{array}$ & $\mathrm{R}_{\text {literature }}$ & $\mathrm{R}_{\text {calc }}$ & Compound & $\begin{array}{c}\text { Area, } \\
\%\end{array}$ \\
\hline 1 & 2 & 3 & \begin{tabular}{|l|}
4 \\
\end{tabular} & 5 & 6 & 7 & 8 \\
\hline $1103 \pm 2$ & 1099 & Thujone & 0.3 & $1778 \pm \mathrm{N} / \mathrm{A}$ & 1762 & $\alpha$-Costol & 0.6 \\
\hline $1480 \pm \mathrm{N} / \mathrm{A}$ & 1464 & Thymylisobutyrate & 0.2 & $1754 \pm 10$ & 1769 & $\beta$-Acoradienol & 0.7 \\
\hline $1486 \pm 3$ & 1503 & $\beta$-Eudesmene & 0.9 & $1778 \pm 4$ & 1777 & $\beta$-Costol & 0.4 \\
\hline $1496 \pm 0$ & 1510 & Dihydro- $\beta$-agarofuran & 2.7 & $1777 \pm \mathrm{N} / \mathrm{A}$ & 1791 & $\begin{array}{l}\text { Eremophila-1,11-dien-9-one, } \\
8 \alpha \text {-hydroxy- }\end{array}$ & 0.3 \\
\hline $1549 \pm 2$ & 1530 & Elemol & 0.6 & $1803 \pm 4$ & 1798 & $\begin{array}{c}\text { 2-Naphthalenemethanol, } \\
\text { 3,4,6,7,8,8a-hexahydro-5- } \\
\text { methyl-8-(1-methylethyl)-, } \\
\text { (8R,8aS)- }\end{array}$ & 0.2 \\
\hline
\end{tabular}

Chemical composition of essential oil of P.vulgaris 
Essential oil of Pulicaria vulgaris (prostrata) ...

Continuation of $\mathrm{Table} 1$

\begin{tabular}{|c|c|c|c|c|c|c|c|}
\hline 1 & 2 & 3 & 4 & 5 & 6 & 7 & 8 \\
\hline $1562 \pm \mathrm{N} / \mathrm{A}$ & 1561 & Dehydronerodiol & 1.3 & $1818 \pm 11$ & 1817 & Zizanoic acid & 0.4 \\
\hline $1551 \pm \mathrm{N} / \mathrm{A}$ & 1568 & Diepicedrene-1-oxide & 0.9 & $1832 \pm \mathrm{N} / \mathrm{A}$ & 1822 & trans-Valerenylacetate & 0.7 \\
\hline $1581 \pm 2$ & 1577 & trans-Sesquisabinenehydrate & 4.1 & $1813 \pm 7$ & 1828 & $\alpha$-Kessylacetate & 0.2 \\
\hline $1581 \pm 2$ & 1580 & Caryophylleneoxide & 0.7 & $1845 \pm \mathrm{N} / \mathrm{A}$ & 1830 & Cyperadione & 0.3 \\
\hline $1610 \pm 10$ & 1590 & Widdrol & 2,0 & $1861 \pm \mathrm{N} / \mathrm{A}$ & 1851 & $\begin{array}{c}\text { (E)-Eremophila-1(10),7(11)- } \\
\text { dien-12-yl acetate }\end{array}$ & 0.3 \\
\hline $1635 \pm N / A$ & 1633 & Patchoulane & 37.4 & $1899 \pm \mathrm{N} / \mathrm{A}$ & 1881 & Corymbolone & 1.2 \\
\hline $1640 \pm 2$ & 1635 & T-Cadinol & 4.7 & $1886 \pm 5$ & 1906 & Oplopanonylacetate & 0.8 \\
\hline $1649 \pm 2$ & 1642 & $\beta$-Eudesmol & 0.3 & $2282 \pm N / A$ & 1916 & Buddledin C * & 13.9 \\
\hline $1642 \pm 2$ & 1646 & $\alpha$-epi-Muurolol & 0.7 & $1939 \pm \mathrm{N} / \mathrm{A}$ & 1956 & Verrucarol & 0.2 \\
\hline $1652 \pm \mathrm{N} / \mathrm{A}$ & 1649 & Cedrane, 8-propoxy- & 0.4 & & 1964 & Unknown 1 & 0.4 \\
\hline $1639 \pm 0$ & 1651 & Oxacyclotetradeca-4,11-diyne & 0.7 & & 2005 & Unknown 2 & 0.4 \\
\hline $1679 \pm 4$ & 1661 & $\begin{array}{c}\text { Cyclohexanemethanol, 4-ethenyl- } \\
\alpha, \alpha, 4 \text {-trimethyl-3-(1-methyl- } \\
\text { ethenyl)-, acetate, } \\
\text { [1R-(1 } 1 \alpha, 3 \alpha, 4 \beta)]-\end{array}$ & 0.3 & & 2049 & Unknown 3 & 0.2 \\
\hline $1680 \pm 18$ & 1667 & Khusimylmethylether & 0.5 & & 2065 & Unknown 4 & 0.7 \\
\hline $1679 \pm \mathrm{N} / \mathrm{A}$ & 1678 & $(E)-\alpha$-Santalal & 0.5 & $2073 \pm \mathrm{N} / \mathrm{A}$ & 2083 & cis-10-Heptadecenoic acid & 0.4 \\
\hline $1693 \pm 3$ & 1703 & Germacrone & 0.2 & & 2134 & Unknown 5 & 0.3 \\
\hline $1717 \pm 4$ & 1719 & (Z)-a-Atlantone & 1.8 & & 2160 & Unknown 6 & 0.6 \\
\hline $1724 \pm \mathrm{N} / \mathrm{A}$ & 1726 & Thujopsenal & 0.3 & $2497 \pm \mathrm{N} / \mathrm{A}$ & 2511 & $\begin{array}{l}\text { Carbonic acid, } \\
\text { eicosyl vinyl ester }\end{array}$ & 0.2 \\
\hline $1748 \pm \mathrm{N} / \mathrm{A}$ & 1734 & $5 \beta, 7 \beta \mathrm{H}, 10 \alpha$-Eudesm-11-en-1 $\alpha$-ol & 0.3 & 2700 & 2695 & Heptacosane & 0.3 \\
\hline $1763 \pm 3$ & 1749 & cis-Lanceol & 0.2 & 2900 & 2892 & Nonacosane & 0.2 \\
\hline $1752 \pm 4$ & 1758 & $\alpha$-Sinensal & 0.2 & & & Total & 86.4 \\
\hline
\end{tabular}

Note. * - Compared with authentic compound.

The DPPH radical scavenging activity of the essential oil of $P$. vulgaris is shown in the Tables 2,3 . Based on the analysis of the data the essential oil $P$. vulgaris at concentration of 0.75 and $1 \mathrm{mg} \mathrm{ml}^{-1}$ has an average antiradical activity compared to BHA.

Table 2

\section{Change in optical density depending on the concentration}

\begin{tabular}{|c|l|c|c|c|c|c|}
\hline \multirow{2}{*}{ No. Sample } & \multicolumn{4}{|c|}{ Values of optical density depending on concentration, $\mathrm{mg} \mathrm{ml}^{-1}$} \\
\cline { 3 - 7 } & & 0.1 & 0.25 & 0.5 & 0.75 & 1.0 \\
\hline 1 & BHA & 0.1362 & 0.1333 & 0.1257 & 0.1202 & 0.1145 \\
\hline 2 & P. vulgaris (aerial part) & 0.6328 & 0.5902 & 0.5380 & 0.4836 & 0.4288 \\
\hline
\end{tabular}

T a b l e 3

Antiradical activity of $P$. vulgaris essential oil

\begin{tabular}{|c|l|c|c|c|c|c|}
\hline \multirow{2}{*}{ No. Sample } & \multicolumn{5}{|c|}{ Concentration of essential oil, $\mathrm{mg} \mathrm{ml}^{-1}$} \\
\cline { 3 - 7 } & & 0.1 & 0.25 & 0.5 & 0.75 & 1.0 \\
\hline 1 & BHA & 80.82 & 81.23 & 82.30 & 83.08 & 83.88 \\
\hline 2 & P. vulgaris (aerial part) & 16.90 & 22.50 & 29.35 & 36.49 & 43.69 \\
\hline
\end{tabular}

In the present study the essential oil of $P$. vulgaris with hexane was tested on cytotoxicity against Artemia salina nauplii. Based on the experiment (Table 4), it can be concluded that the essential oil P. vulgaris in all tested concentrations exhibited cytotoxicity; the mortality of nauplii was $96 \%$. 
Cytotoxic activity of essential oil of $P$. vulgaris

\begin{tabular}{|c|c|c|c|c|c|c|c|c|c|}
\hline \multirow[t]{2}{*}{ Parallel } & \multicolumn{2}{|c|}{$\begin{array}{l}\text { Amount of nauplii } \\
\text { in control }\end{array}$} & \multicolumn{3}{|c|}{$\begin{array}{l}\text { Amount of nauplii in a sam- } \\
\text { ple }\end{array}$} & \multirow{2}{*}{$\begin{array}{c}\text { \% surviving } \\
\text { nauplii in } \\
\text { control }\end{array}$} & \multirow{2}{*}{$\begin{array}{l}\% \text { surviving } \\
\text { nauplii in the } \\
\text { sample }\end{array}$} & \multirow{2}{*}{$\begin{array}{c}\text { Mortality, } \\
\text { P, \% }\end{array}$} & \multirow{2}{*}{$\begin{array}{c}\text { Presence of } \\
\text { neurotoxicity, } \\
\%\end{array}$} \\
\hline & survivors & died & survivors & died & Parallel & & & & \\
\hline \multicolumn{10}{|c|}{$10.0 \mathrm{mg} \mathrm{ml}^{-1}$} \\
\hline 1 & 25 & 1 & 0 & 31 & 0 & \multirow{4}{*}{96} & \multirow{4}{*}{0} & \multirow{4}{*}{96} & \multirow{4}{*}{0} \\
\hline 2 & 26 & 1 & 0 & 30 & 0 & & & & \\
\hline 3 & 30 & 0 & 0 & 27 & 0 & & & & \\
\hline Average & 25 & 1 & 0 & 29 & 0 & & & & \\
\hline \multicolumn{10}{|c|}{$5.0 \mathrm{mg} \mathrm{ml}^{-1}$} \\
\hline 1 & 25 & 1 & 0 & 30 & 0 & \multirow{4}{*}{96} & \multirow{4}{*}{0} & \multirow{4}{*}{96} & \multirow{4}{*}{0} \\
\hline 2 & 26 & 1 & 0 & 24 & 0 & & & & \\
\hline 3 & 30 & 0 & 0 & 24 & 0 & & & & \\
\hline Average & 25 & 1 & 0 & 26 & 0 & & & & \\
\hline \multicolumn{10}{|c|}{$1.0 \mathrm{mg} \mathrm{ml}^{-1}$} \\
\hline 1 & 25 & 1 & 0 & 28 & 0 & \multirow{4}{*}{96} & \multirow{4}{*}{0} & \multirow{4}{*}{96} & \multirow{4}{*}{0} \\
\hline 2 & 26 & 1 & 0 & 28 & 0 & & & & \\
\hline 3 & 30 & 0 & 0 & 26 & 0 & & & & \\
\hline Average & 27 & 1 & 0 & 27 & 0 & & & & \\
\hline
\end{tabular}

\section{Conclusions}

The results of the GC/MS experiment was showed that the main components of the essential oil of P. vulagaris from Akmola region (Kazakhstan) were patchoulane (37.4\%), buddledin C (13.9\%), T-cadinol $(4.7 \%)$, trans-sesquisabinene hydrate $(4.1 \%)$ and dyhydro- $\beta$-agarofuran $(2.7 \%)$. Six components were identified as unknown $(\Sigma 2.6 \%)$. Antiradical activity test were showed that the essential oil has average activity at concentration 0.75 and $1 \mathrm{mg} \mathrm{ml}^{-1}$ compared to BHA. It should be noted that in this study we investigated the antiradical activity of the essential oil for the first time. The results of cytotoxic activity assay on Artemia salina nauplii exhibited a good activity of the essential oil in all tested concentrations, mortality was $96 \%$. According to a literature review, the patchoulane is the main component of this essential oil and its derivatives were demonstrated moderate cytotoxic activity in human ovarian cancer cells [15].

It can be concluded that the essential oil of $P$. vulgaris from Kazakhstan is differed significantly by component composition of essential oils from Italy and Iran and it can be a good source of biological active compounds.

This research has been funded by the Science Committee of the Ministry of Education and Science of the Republic of Kazakhstan (Grant No. AP08051842).

\section{References}

1 Williams C.A. Variations in lipophilic and vacuolar flavonoids among European Pulicaria species / C.A. Williams, J.B. Harborne, J.R. Greenham, R.J. Grayer, G.C. Kite, J. Eagles // Phytochemistry. — 2003. — Vol. 64. — P. 275-283. DOI: $10.1016 / \mathrm{S} 0031-9422(03) 00207-3$

2 Chhetri K.B. A Survey of chemical composition and biological activities of Yemeni aromatic medicinal plants / K.B. Chhetri, N.A. Awadh Ali, W.N. Setzer // Medicines. — 2015. — Vol. 2. - P. 67-92. DOI:10.3390/medicines2020067

3 Al-Hajj N.Q.M. Antimicrobial and antioxidant activities of the essential oils of some aromatic medicinal plants (Pulicaria inuloides - Asteraceae and Ocimum forskolei - Lamiaceae Trop.) / N.Q.M. Al-Hajj, H.X. Wang, C. Ma, Z. Lou, M. Bashari, R. Thabit// Journal Pharmaceutical Research. - 2014. - Vol. 13. - P. 1287-1293. DOI: 10.4314/tjpr.v13i8.13

4 Fawzy G.A. Chemical composition and biological evaluation of essential oils of Pulicaria jaubertii / G.A. Fawzy, H.Y. Al Ati, A.A. El Gamal // Pharmacognosy Magazine. - 2013. - Vol. 9. - P. 28-32. DOI:10.4103/0973-1296.108133

5 Ali N.A.A. Chemical composition, antimicrobial, antiradical and anticholinesterase activity of the essential oil of Pulicaria stephanocarpa from Soqotra / N.A.A. Ali, R.A. Crouch, M.A. Al-Fatimi, N. Arnold, A. Teichert, W.N. Setzer, L. Wessjohann // Natural Products Communication. — 2012. — Vol. 7. - P. 113-116. DOI: 10.1177/1934578X1200700137

6 Hanbali F.E.L. Chemical composition and antibacterial activity of essential oil of Pulicaria odora L. / F.E.L. Hanbali, M. Akssira, A. Ezoubeiri, C.A. Gadhi, F. Mellouki, A. Benherraf, A.M. Blazquez, H. Boira // Journal of Ethnopharmacology. 2005. - Vol. 99. - P. 399-401. DOI: 10.1016/j.jep.2005.01.012 
7 Boumaraf M. Esential oil composition of Pulicaria undulata (L.) DC. (Asteraceae) growing in Algeria / M. Boumaraf, R. Mekkiou, S. Benyahia, J.C. Chalchat, P. Chalard, F. Benayache, S. Benayache // International Journal of Pharmacognosy and Phytochemical Research. - 2016. - Vol. 8, No. 5. - P. 746-749.

8 Ali N.A. Chemical composition and biological activity of essential oil from Pulicaria undulata from Yemen / N.A. Ali, F.S. Sharopov, M. Alhaj, G.M. Hill, A. Porzel, N. Arnold, W.N. Setzer, J. Schmidt, L. Wessjohann // Natural Product Communications. - 2012. - Vol. 7, No. 2. - P. 257-260.

9 Mustafa A.M. Chemical composition and biological activities of the essential oil from Pulicaria undulata (L.) C.A. Mey. Growing wild in Egypt / A.M. Mustafa, S.I. Eldahmy, G. Caprioli, M. Bramucci, L. Quassinti, G. Lupidi, D. Beghelli, S. Vittori, F. Maggi // Natural Product Research. - 2018. — P. 1-5. DOI: 10.1080/14786419.2018.1534107

10 Ravandeh M. Screening of chemical composition of essential oil, mineral elements and antioxidant activity in Pulicaria undulata (L.) C.A. Mey from Iran / M. Ravandeh, J. Valizadeh, M. Noroozifar, M. Khorasani-Motlagh // Journal of Medicinal Plants Research. - 2011. - Vol. 5, No. 10. - P. 2035-2040.

11 Павлов Н.В. Флора Казахстана / Н.В. Павлов. - Алма-Ата: Наука, 1966. - Т. 9. — С. 318.

12 Casiglia S. Chemical composition of the essential oil from Pulicaria vulgaris var. graeca (Sch.-Bip.) Fiori (Asteraceae) growing wild in Sicily and its antimicrobial activity / S. Casiglia, L. Riccobono, M. Bruno, F. Senatore, F. Senatore // Natural Product Research. - 2015. DOI: 10.1080/14786419.2015.1055267

13 Sharifi-Rad J. Chemical composition and biological activity of Pulicaria vulgaris Essential oil from Iran / J. Sharifi-Rad, A. Miri, S.M. Hoseini-Alfatemi, M. Sharifi-Rad, W.N. Setzer, A. Hadjiakhoondi // Natural Product Communications. — 2014. Vol. 9, No. 11. - P. 1633-1636. DOI10.1177/1934578x1400901126

14 Sharifi-Rad M. Pulicaria vulgaris Gaertn. essential oil: an alternative or complementary treatment for Leishmaniasis / M. Sharifi-Rad, B. Salehi, J. Sharifi-Rad, W.N. Setzer, M. Iriti // Cellular and Molecular Biology. — 2018. — Vol. 64, No. 8. — P. 18-21. DOI: $10.14715 / \mathrm{cmb} / 2018.64 .8 .3$

15 Ahn J.H. 6-Acetoxy Cyperene, a Patchoulane-type Sesquiterpene isolated from Cyperus rotundus Rhizomes Induces Caspase-dependent apoptosis in human ovarian cancer cells / J.H. Ahn, T.W. Lee, H. Byun, B. Ryu, K.T. Lee, D.S. Jang, J.H. Choi // Phytotherapy research. — 2015. — Vol. 29. — P. 1330-1338. DOI: 10.1002/ptr.5385

\author{
А.Ш. Жанжаксина, Е.М. Сүлеймен, М.Ю. Ишмуратова, Ж.Б. Искакова, \\ Т.М. Сейлханов, Д.А. Бірімжанова, Р.Н. Сүлеймен
}

\title{
Pulicaria vulgaris (prostrata) эфир майы және оның биологиялық белсенділігі
}

\begin{abstract}
Зерттеудің мақсаты - Ақмола облысында (Қазақстан) өсетін Pulicaria vulgaris (prostrata) эфир майының химиялық құрамын, радикалға қарсы және цитоуыттылық белсенділігін зерттеу. Эфир майы гидродистилляция тәсілімен алынды және газды хроматография - масс спектрометрия (ГХ/MC) арқылы зерттелді. Нәтижесінде 86.4 \% құрайтын 49 компонент анықталды, ал негізгі компоненттері - пачулан $(37,4 \%)$, буддледин С $(13,9 \%)$, Т-кадинол $(4,7 \%)$, транс-сесквисабинен гидраты $(4,1 \%)$, дигидро- $\beta$-агарофуран $(2,7 \%),(Z)$ - $\alpha$-атлантон $(1,8 \%)$ және коримболон $(1,2 \%)$ болды. Алты компонент белгісіз болып анықталды (2,6\%). Антиоксиданттық белсенділік DPPH еркін радикалдарды қолдану арқылы бағаланды және эфир майы 0,75 және 1 мг/мл концентрацияларда бутилгидроксианизолға (БГА) қарағанда орташа радикалға қарсы белсенділігін көрсетті. Бұл зерттеуде P. vulgaris эфир майының радикалға қарсы белсенділігінің нәтижелері алғаш рет жарияланды. Artemia salina дернәсілдеріне қарсы цитоуыттылық белсенділік нәтижелеріне сәйкес эфир майы барлық сыналған концентрацияларда өлімге әкелетін уыттылығы бар деген қорытындыға келді. Авторлар бұл нәтижені эфир майының негізгі компонентті — пачуланның аналық бездің қатерлі ісік жасушаларына қарсы белсенділігімен белгілі болуымен түсіндіреді.
\end{abstract}

Кілт сөздер: Pulicaria vulgaris, эфир майы, пачулан, антиоксиданттық, цитоуыттылық белсенділіктер.

\author{
А.Ш. Жанжаксина, Е.М. Сулеймен, М.Ю. Ишмуратова, Ж.Б. Искакова, \\ Т.М. Сейлханов, Д.А. Биримжанова, Р.Н. Сулеймен
}

\section{Эфирное масло Pulicaria vulgaris (prostrata) и его биологическая активность}

Целью данного исследования является изучение химического компонентного состава, антирадикальной и цитотоксической активности эфирного масла Pulicaria vulgaris (prostrata), дико произрастающего в Акмолинской области (Казахстан). Эфирное масло было получено гидродистилляцией и исследовано методом газовой хроматографии - масс-спектрометрии (ГХ/МС). В результате было идентифицировано 49 компонентов, составляющих 86,4\%. Основными компонентами были пачулан $(37,4 \%)$, буддледин C (13,9\%), Т-кадинол $(4,7 \%)$, транс-сесквисабинен гидрат $(4,1 \%)$, дигидро- $\beta$ агарофуран $(2,7 \%),(Z)-\alpha$-атлантон $(1,8 \%)$ и коримболон $(1,2 \%)$. Шесть компонентов были определены как неизвестные $(2,6 \%)$. Антирадикальную активность оценивали с использованием свободных радикалов DPPH, и данное эфирное масло показало умеренную антирадикальную активность по срав- 
нению с бутилгидроксианизолом (БГА) при концентрациях 0,75 и 1 мг/мл. В этом исследовании результаты антирадикальной активности эфирного масла $P$. vulgaris публикуются впервые. По результатам цитотоксической активности в отношении личинок Artemia salina было сделано заключение, что эфирное масло обладает хорошей летальной токсичностью при всех испытанных концентрациях. Авторы объясняют этот результат наличием основного компонента — пачулана, известного своей активностью в отношении раковых клеток яичников.

Ключевые слова: Pulicaria vulgaris, эфирное масло, пачулан, антирадикальная, цитотоксическая активность.

\section{References}

1 Williams, C.A., Harborne, J.B., Greenham, J.R., Grayer, R.J., Kite, G.C. \& Eagles, J. (2003). Variations in lipophilic and vacuolar flavonoids among European Pulicaria species. Phytochemistry, 64, 275-283. DOI: 10.1016/S0031-9422(03)00207-3

2 Chhetri, K.B., Awadh Ali, N.A. \& Setzer, W.N. (2015). A Survey of chemical composition and biological activities of Yemeni aromatic medicinal plants. Medicines, 2, 67-92. DOI:10.3390/medicines2020067

3 Al-Hajj, N.Q.M., Wang, H.X., Ma, C., Lou, Z., Bashari, M. \& Thabit R. (2014). Antimicrobial and antioxidant activities of the essential oils of some aromatic medicinal plants (Pulicaria inuloides - Asteraceae and Ocimum forskolei - Lamiaceae Trop.). Journal Pharmaceutical Research, 13, 1287-1293. DOI: 10.4314/tjpr.v13i8.13

4 Fawzy, G.A., Al Ati, H.Y. \& El Gamal, A.A. (2013). Chemical composition and biological evaluation of essential oils of Pulicaria jaubertii. Pharmacognosy Magazine, 9, 28-32. DOI:10.4103/0973-1296.108133

5 Ali, N.A.A., Crouch, R.A., Al-Fatimi, M.A., Arnold, N., Teichert, A., Setzer, W.N. \& Wessjohann, L. (2012). Chemical composition, antimicrobial, antiradical and anticholinesterase activity of the essential oil of Pulicaria stephanocarpa from Soqotra. Natural Products Communication, 7, 113-116. DOI: 10.1177/1934578X1200700137

6 Hanbali, F.E.L., Akssira, M., Ezoubeiri, A., Gadhi, C.A., Mellouki, F., Benherraf, A., \& Blazquez, A.M. et al. (2005). Chemical composition and antibacterial activity of essential oil of Pulicaria odora L. Journal of Ethnopharmacology, 99, 399-401. DOI: 10.1016/j.jep.2005.01.012

7 Boumaraf, M., Mekkiou, R., Benyahia, S., Chalchat, J.C., Chalard, P., Benayache, F. \& Benayache S. (2016). Essential oil composition of Pulicaria undulata (L.) DC. (Asteraceae) growing in Algeria. International Journal of Pharmacognosy and Phytochemical Research, 8(5), 746-749.

8 Ali, N.A., Sharopov, F.S., Alhaj, M., Hill, G.M., Porzel, A., Arnold, N., \& Setzer, W.N., et al. (2012). Chemical composition and biological activity of essential oil from Pulicaria undulata from Yemen. Natural Product Communications, 7(2), 257-260.

9 Mustafa, A.M., Eldahmy, S.I., Caprioli, G., Bramucci, M., Quassinti, L., Lupidi, G., \& Beghelli, D. et al. (2018). Chemical composition and biological activities of the essential oil from Pulicaria undulata (L.) C.A. Mey. Growing wild in. Natural Product Research, 2018, 1-5. DOI: 10.1080/14786419.2018.1534107

10 Ravandeh, M., Valizadeh, J., Noroozifar, M. \& Khorasani-Motlagh, M. (2011). Screening of chemical composition of essential oil, mineral elements and antioxidant activity in Pulicaria undulata (L.) C.A. Mey from Iran. Journal of Medicinal Plants Research, 5 (10), 2035-2040.

11 Pavlov, N.V. (1966). Flora Kazakhstana [Flora of Kazakhstan]. Alma-Ata: Nauka [in Russian].

12 Casiglia, S., Riccobono, L., Bruno, M., Senatore, F. \& Senatore, F. (2015). Chemical composition of the essential oil from Pulicaria vulgaris var. graeca (Sch.-Bip.) Fiori (Asteraceae) growing wild in Sicily and its antimicrobial activity. Natural Product Research. DOI: 10.1080/14786419.2015.1055267

13 Sharifi-Rad, J., Miri, A., Hoseini-Alfatemi, S.M., Sharifi-Rad, M., Setzer, W.N. \& Hadjiakhoondi, A. (2014). Chemical composition and biological activity of Pulicaria vulgaris Essential oil from Iran. Natural Product Communications, 9(11), $1633-1636$. DOI10.1177/1934578x1400901126

14 Sharifi-Rad, M., Salehi, B., Sharifi-Rad, J., Setzer, W.N. \& Iriti, M. (2018). Pulicaria vulgaris Gaertn. essential oil: an alternative or complementary treatment for Leishmaniasis. Cellular and Molecular Biology, 64(8), 18-21. DOI: $10.14715 / \mathrm{cmb} / 2018.64 .8 .3$

15 Ahn, J.H., Lee, T.W., Byun, H., Ryu, B., Lee, K.T., Jang, D.S. \& Choi, J.H. (2015). 6-Acetoxy Cyperene, a Patchoulane-type Sesquiterpene isolated from Cyperus rotundus Rhizomes Induces Caspase-dependent apoptosis in human ovarian cancer cells. Phytotherapy research, 29, 1330-1338. DOI: 10.1002/ptr.5385 